Supporting Information

\title{
A Highly Sensitive Chiral Shift Reagent Bearing Two Zinc Porphyrins
}

Tadashi Ema,* Nozomi Ouchi, Tokuhiro Doi, Toshinobu Korenaga, and Takashi Sakai* Department of Applied Chemistry, Faculty of Engineering, Okayama University, Tsushima, Okayama 700-8530, Japan



Racemic compound 2 was prepared as reported previously. ${ }^{1}$ To a mixture of 2 (135 mg, 0.205 $\mathrm{mmol}$ ) and lipase PS-C II (Amano Enzyme, $900 \mathrm{mg}$ ) in dry $i-\operatorname{Pr}_{2} \mathrm{O}(150 \mathrm{~mL})$ was added vinyl acetate $(535 \mathrm{mg}, 6.21 \mathrm{mmol})$ at $60{ }^{\circ} \mathrm{C}$. After the mixture was stirred at $60{ }^{\circ} \mathrm{C}$ for $12 \mathrm{~h}$, the mixture was filtered through Celite. Ester $(R)-3$ and alcohol $(S)-2$ were separated by silica gel column chromatography and characterized as reported previously: ${ }^{1}(R)-3: 45 \%$ yield; $>98 \%$ ee; TLC $\left(\mathrm{CHCl}_{3}\right) R_{f}=0.49 ;{ }^{1} \mathrm{H} \mathrm{NMR}\left(\mathrm{CDCl}_{3}, 600 \mathrm{MHz}\right) \delta-2.77(\mathrm{br} \mathrm{s}, 2 \mathrm{H}), 1.84(\mathrm{~d}, J=6.6 \mathrm{~Hz}, 3 \mathrm{H}), 2.27$ (s, 3H), 6.26 (q, $J=6.6 \mathrm{~Hz}, 1 \mathrm{H}), 7.74-7.79(\mathrm{~m}, 11 \mathrm{H}), 8.20-8.23(\mathrm{~m}, 8 \mathrm{H}), 8.85$ (s, 8H); HPLC: Chiralpak AD-H, hexane: $i-\mathrm{PrOH}=98: 2$, flow rate $0.3 \mathrm{~mL} / \mathrm{min}$, detection $420 \mathrm{~nm},(R) 79.2 \mathrm{~min}$, (S) 106 min. (S)-2: 47\% yield; >98\% ee; TLC $\left(\mathrm{CHCl}_{3}\right) R_{f}=0.15 ;{ }^{1} \mathrm{H} \mathrm{NMR}\left(\mathrm{CDCl}_{3}, 600 \mathrm{MHz}\right) \delta$ -2.75 (br s, 2H), 1.81 (d, J=6.6 Hz, 3H), 2.10 (br s, 1H), 5.26 (q, J = 6.6 Hz, 1H), 7.74-7.80 (m, 11H), 8.20-8.24 (m, 8H), 8.86 (s, 8H); HPLC: Chiralpak AD-H, hexane: $i-\mathrm{PrOH}=92: 8$, flow rate $0.3 \mathrm{~mL} / \mathrm{min}$, detection $420 \mathrm{~nm},(R) 45.2 \mathrm{~min},(S) 53.0 \mathrm{~min}$. To a solution of $(R)-3(62 \mathrm{mg}, 88$ $\mu \mathrm{mol})$ in THF $(60 \mathrm{~mL})$ was added aqueous $\mathrm{NaOH}(0.24 \mathrm{M}, 12 \mathrm{~mL})$. The mixture was heated at reflux for $19 \mathrm{~h}$. After brine $(40 \mathrm{~mL})$ was added to the mixture, the organic layer was separated, dried over $\mathrm{Na}_{2} \mathrm{SO}_{4}$, and concentrated. The product was purified by silica gel column chromatography to afford $(R)-2$ as a purple solid (57 $\mathrm{mg}, 98 \%$ yield). 


\section{Preparation of $\operatorname{Bis}\{(S)$-1-[4-(10,15,20-triphenyl-5-porphyrinyl)phenyl]ethyl $\}$ 5-}

\section{tert-butyl-1,3-benzenedicarboxylate $((S, S)-1 \mathrm{a})$ and $(R, R)-1 \mathrm{a}$.}

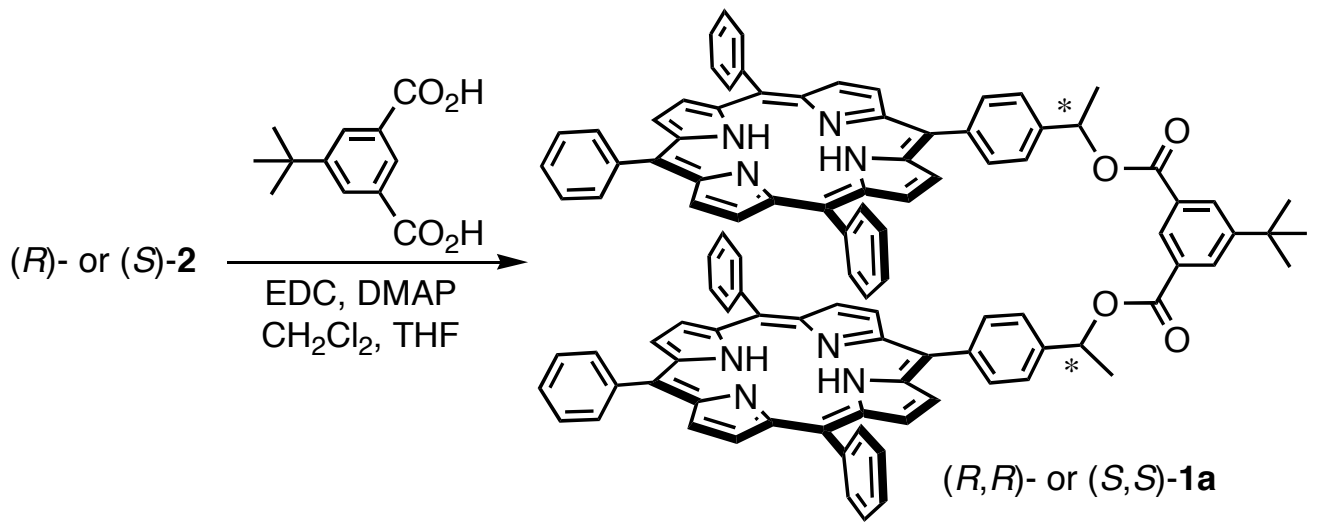

To a solution of $(S)-2(135 \mathrm{mg}, 0.205 \mathrm{mmol})$ in dry $\mathrm{CH}_{2} \mathrm{Cl}_{2}(1.9 \mathrm{~mL})$ was added a solution of 5tert-butylisophthalic acid (19 mg, $85 \mu \mathrm{mol})$ in dry THF $(1.9 \mathrm{~mL})$. To the mixture was added 1-(3dimethylaminopropyl)-3-ethylcarbodiimide hydrochloride (EDC• $\mathrm{HCl})(33 \mathrm{mg}, 0.17 \mathrm{mmol})$ and 4-(dimethylamino)pyridine (DMAP) (42 mg, $0.34 \mathrm{mmol}$ ). After the mixture was stirred under $\mathrm{N}_{2}$ at room temperature for $3 \mathrm{~h}, \mathrm{EDC} \cdot \mathrm{HCl}(33 \mathrm{mg}, 0.17 \mathrm{mmol})$ and DMAP (42 mg, $0.34 \mathrm{mmol})$ were added. The mixture was stirred at room temperature for $20 \mathrm{~h}$. After $\mathrm{H}_{2} \mathrm{O}(1 \mathrm{~mL})$ and aqueous $3 \%$ $\mathrm{HCl}$ was added to adjust the solution to $\mathrm{pH} \mathrm{3,} \mathrm{the} \mathrm{organic} \mathrm{layer} \mathrm{was} \mathrm{separated,} \mathrm{washed} \mathrm{with}$ aqueous $\mathrm{NaHCO}_{3}$, dried over $\mathrm{Na}_{2} \mathrm{SO}_{4}$, and concentrated. The product was purified by silica gel column chromatography $\left(\mathrm{CHCl}_{3}\right)$ to afford $(S, S)$-1a as a purple solid $(104 \mathrm{mg}, 81 \%)$. $(R, R)-\mathbf{1 a}$ was also synthesized from $(R)-2$ in the same way: $\mathrm{mp}>300{ }^{\circ} \mathrm{C} ; \mathrm{TLC}\left(\mathrm{CHCl}_{3}\right) R_{f}=0.48 ;{ }^{1} \mathrm{H} \mathrm{NMR}$ $\left(\mathrm{CDCl}_{3}, 600 \mathrm{MHz}\right) \delta-2.80(\mathrm{~s}, 4 \mathrm{H}), 1.49(\mathrm{~s}, 9 \mathrm{H}), 2.03(\mathrm{~d}, J=6.6 \mathrm{~Hz}, 6 \mathrm{H}), 6.56(\mathrm{q}, J=6.6 \mathrm{~Hz}$, 2H), 7.65-7.88 (m, 22H), 8.15-8.25 (m, 16H), 8.52 (d, $J=1.8 \mathrm{~Hz}, 2 \mathrm{H}), 8.79-8.86(\mathrm{~m}, 16 \mathrm{H}), 8.93$ $(\mathrm{t}, J=1.8 \mathrm{~Hz}, 1 \mathrm{H}) ;{ }^{13} \mathrm{C} \mathrm{NMR}\left(\mathrm{CDCl}_{3}, 150 \mathrm{MHz}\right) \delta 22.8,31.3,35.1,73.4,119.5,120.1,120.2$, 124.4, 126.6, 126.7, 127.6, 127.7, 128.4, 130.2, 130.9, 131.3, 134.51, 134.54, 134.8, 141.1, 141.8, 142.07, 142.12, 152.4, 165.7; IR (KBr) 3314, 1724, $1231 \mathrm{~cm}^{-1}$; MS (FAB, nitrobenzyl alcohol) calcd for $\mathrm{C}_{104} \mathrm{H}_{79} \mathrm{~N}_{8} \mathrm{O}_{4}$ 1503, found $1503(\mathrm{M}+1)$; HRMS (FAB, nitrobenzyl alcohol) calcd for $\mathrm{C}_{104} \mathrm{H}_{79} \mathrm{~N}_{8} \mathrm{O}_{4}$ 1503.6224, found 1503.6191 $(\mathrm{M}+1)$; UV-Vis $\left(\mathrm{CHCl}_{3}\right) \lambda_{\max }(\log \varepsilon) 419$ (5.95), 516 (4.56), 551 (4.19), 590 (4.03), 645 (3.88). 


\section{Preparation of Zinc Complexes $(S, S)-1 \mathrm{~b}$ and $(R, R)-1 \mathrm{~b}$.}

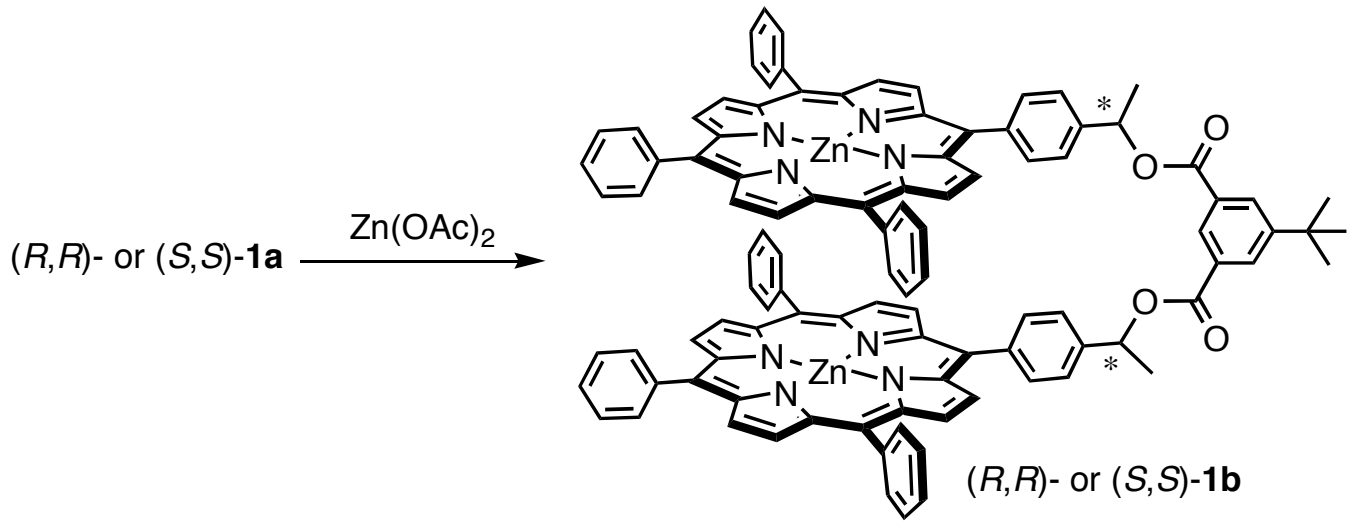

To a solution of $(S, S)-\mathbf{1 a}(70 \mathrm{mg}, 47 \mu \mathrm{mol})$ in $\mathrm{CHCl}_{3}(13 \mathrm{~mL})$ was added a solution of $\mathrm{Zn}(\mathrm{OAc})_{2} \cdot 2 \mathrm{H}_{2} \mathrm{O}(206 \mathrm{mg}, 0.938 \mathrm{mmol})$ in $\mathrm{MeOH}(5 \mathrm{~mL})$. The mixture was heated at reflux for $1.5 \mathrm{~h}$. The progress of the reaction was monitored by TLC and UV-Vis spectroscopy. After brine $(50 \mathrm{~mL})$ was added to the mixture, the organic layer was separated, and aqueous layer was extracted with $\mathrm{CHCl}_{3}(10 \mathrm{~mL} \times 2)$. The organic layer was dried over $\mathrm{Na}_{2} \mathrm{SO}_{4}$, and concentrated. The product was purified by silica gel column chromatography $\left(\mathrm{CHCl}_{3}\right)$ and recrystallization from $\mathrm{CHCl}_{3} /$ hexane to afford $(S, S)-\mathbf{1 b}$ as purple crystals $(60 \mathrm{mg}, 78 \%) .(R, R)-\mathbf{1 b}$ was also synthesized from $(R, R)-\mathbf{1 a}$ in the same way: $\mathrm{mp}>300{ }^{\circ} \mathrm{C}$; TLC $\left(\mathrm{CHCl}_{3}\right) R_{f}=0.23 ;{ }^{1} \mathrm{H}$ NMR $\left(\mathrm{CDCl}_{3}, 600 \mathrm{MHz}\right) \delta 1.50(\mathrm{~s}, 9 \mathrm{H}), 2.04(\mathrm{~d}, J=6.6 \mathrm{~Hz}, 6 \mathrm{H}), 6.57(\mathrm{q}, J=6.6 \mathrm{~Hz}, 2 \mathrm{H}), 7.65-7.88$ $(\mathrm{m}, 22 \mathrm{H}), 8.16-8.26(\mathrm{~m}, 16 \mathrm{H}), 8.53(\mathrm{~d}, J=1.8 \mathrm{~Hz}, 2 \mathrm{H}), 8.89-8.96(\mathrm{~m}, 17 \mathrm{H}) ;{ }^{13} \mathrm{C} \mathrm{NMR}\left(\mathrm{CDCl}_{3}\right.$, $150 \mathrm{MHz}) \delta 22.8,31.3,35.1,73.4,120.6,121.1,121.2,124.3,126.48,126.54,127.4,127.5$, $128.4,130.9,131.3,131.98,132.01,134.38,134.40,134.7,140.8,142.5,142.7,142.8,150.13$, 150.17, 150.18, 150.20, 152.4, 165.8; IR (KBr) 1724, $1232 \mathrm{~cm}^{-1}$; MS (FAB, nitrobenzyl alcohol) calcd for $\mathrm{C}_{104} \mathrm{H}_{75} \mathrm{~N}_{8} \mathrm{O}_{4} \mathrm{Zn}_{2} 1629$, found cluster peaks around $1629(\mathrm{M}+1)$; UV-Vis $\left(\mathrm{CHCl}_{3}\right) \lambda_{\max }$ (log ع) 419 (6.03), 510 (3.79), 547 (4.65), 585 (3.85).

\section{Preparation of Amines.}

Enantiomerically pure amines 4-6 and $\mathbf{9}$ as well as achiral diamine $\mathbf{8}$ were purchased. L-Lys-NEt $7^{2}$ and aziridine $\mathbf{1 0}^{3}$ were synthesized according to the literature. Enantiomerically pure $(2 R, 3 S)$ $\mathbf{1 0}$ was prepared by the lipase-catalyzed kinetic resolution of racemic $\mathbf{1 0}$ as reported recently by us. ${ }^{3}$ Racemic isoxazoline $\mathbf{1 1}^{4 \mathrm{a}}$ was synthesized according to the literature. ${ }^{4}$ 


\section{General Procedure for UV-Vis Titrations.}

To a solution $(3.0 \mathrm{~mL})$ of $(R, R)$ - or $(S, S)$-1b in dry $\mathrm{CHCl}_{3}$ (Aldrich, stabilized with amylene, stored over molecular sieves $3 \mathrm{~A})(1.65 \mu \mathrm{M})$ was added a solution of amine in dry $\mathrm{CHCl}_{3}$ at a constant temperature in a thermostat. The change in absorbance at $419 \mathrm{~nm}$ was monitored at several different concentrations of amine. Assuming the 1:1 complexation, the association constant was calculated by the nonlinear least-squares curve-fitting method.

\section{Typical Procedure for ${ }^{1} \mathrm{H}$ NMR Measurements.}

Dry $\mathrm{CDCl}_{3}$ was prepared by passing through a basic alumina short column, and it was stored over molecular sieves $3 \mathrm{~A}$. To a solution $(50 \mu \mathrm{L})$ of $(R)$ - or $(S)$-amine $(0.328 \mu \mathrm{mol})$ in dry $\mathrm{CDCl}_{3}$ was added $\mathrm{CDCl}_{3}(450 \mu \mathrm{L})$ followed by a solution $(100 \mu \mathrm{L})$ of $(R, R)-$ or $(S, S)-\mathbf{1 b}(1.07 \mathrm{mg}, 0.656$ $\mu \mathrm{mol})$ in dry $\mathrm{CDCl}_{3} .{ }^{1} \mathrm{H}$ NMR was measured at $22{ }^{\circ} \mathrm{C}(600 \mathrm{MHz})$ and/or $-40{ }^{\circ} \mathrm{C}(300 \mathrm{MHz})$. Then, a solution $(50 \mu \mathrm{L})$ of the opposite enantiomer of the amine $(0.328 \mu \mathrm{mol})$ in $\mathrm{CDCl}_{3}$ was added to measure the difference in chemical shifts between the enantiomers at $22{ }^{\circ} \mathrm{C}$ and $-40{ }^{\circ} \mathrm{C}$.

\section{References}

(1) Ema, T.; Jittani, M.; Furuie, K.; Utaka, M.; Sakai, T. J. Org. Chem. 2002, 67, 2144-2151.

(2) Hayashi, T.; Aya, T.; Nonoguchi, M.; Mizutani, T.; Hisaeda, Y.; Kitagawa, S.; Ogoshi, H. Tetrahedron 2002, 58, 2803-2811.

(3) Sakai, T.; Liu, Y.; Ohta, H.; Korenaga, T.; Ema, T. J. Org. Chem. 2005, 70, 1369-1375.

(4) (a) Jäger, V.; Schwab, W.; Buss, V. Angew. Chem. Int. Ed. Engl. 1981, 20, 601-603. (b) Jung, M. E.; Vu, B. T. Tetrahedron Lett. 1996, 37, 451-454. 


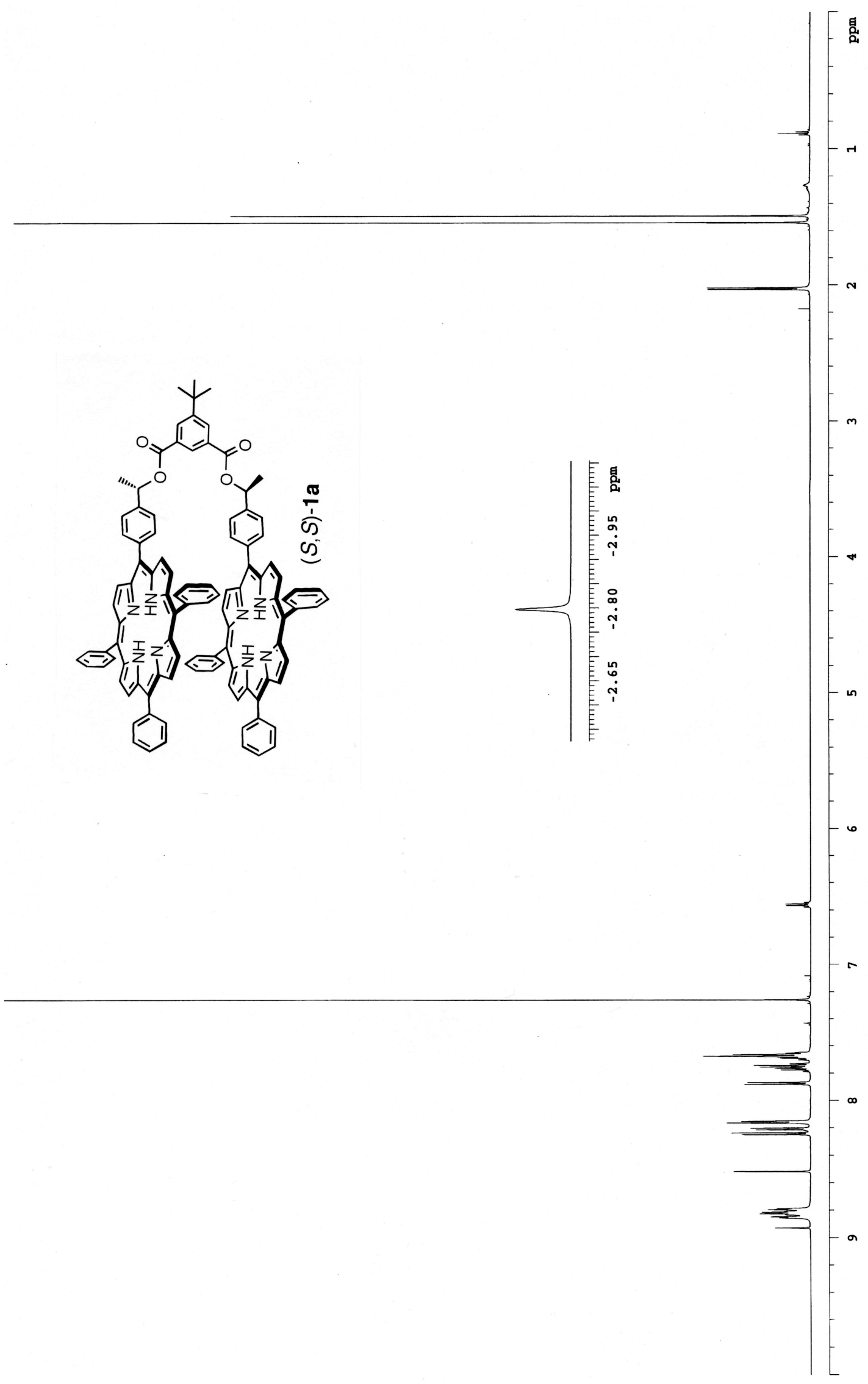

S- 5 


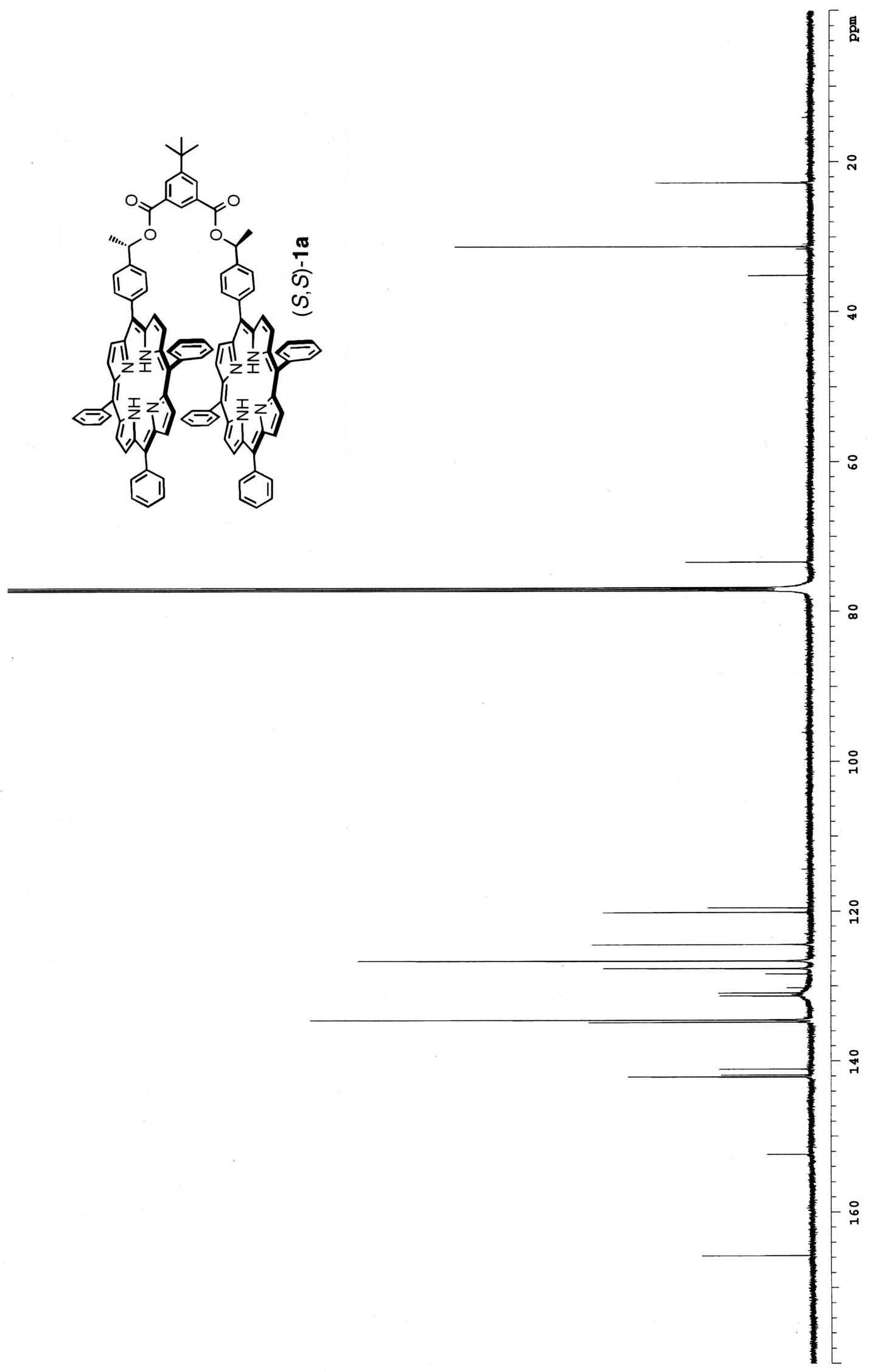

S- 6 


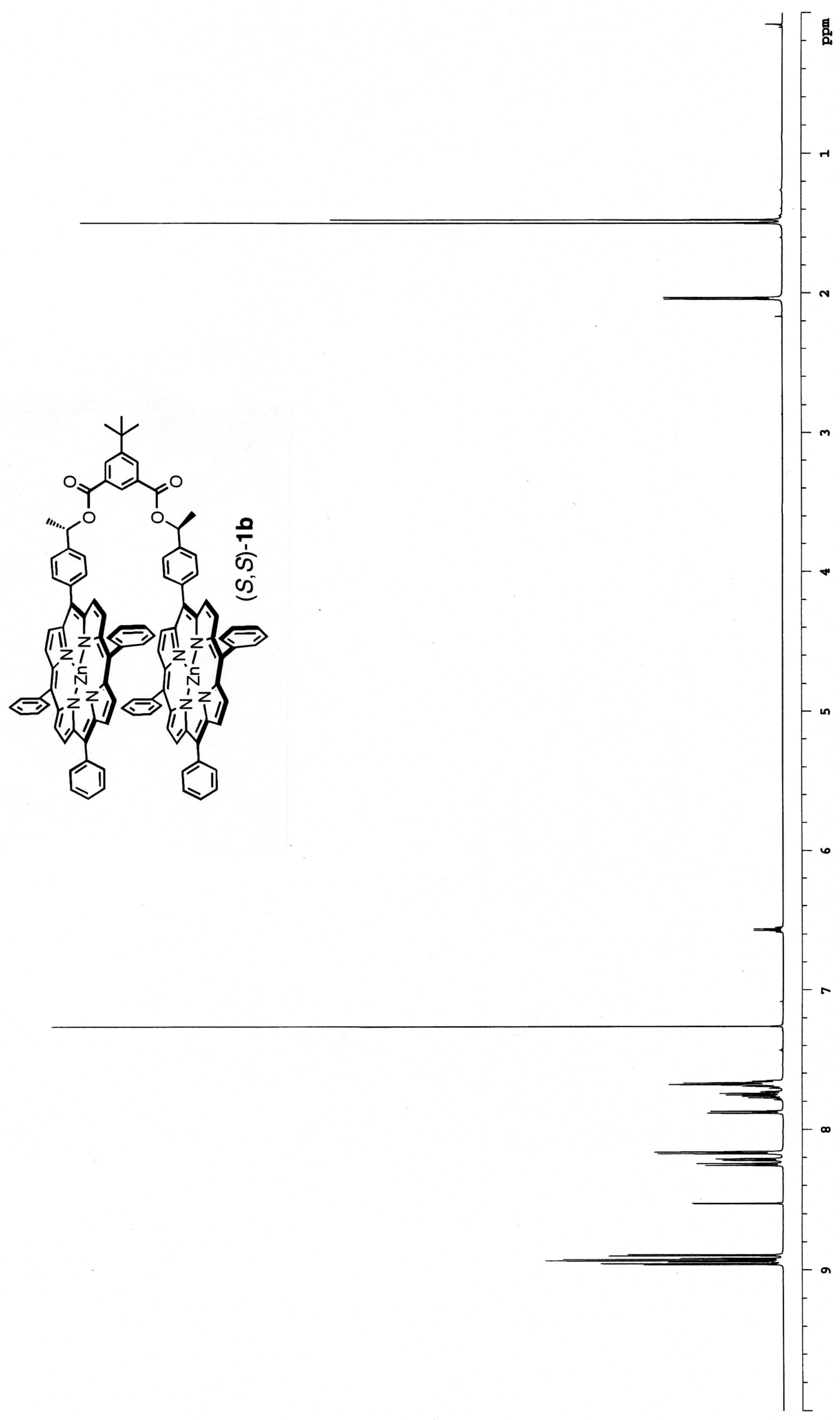

S- 7 


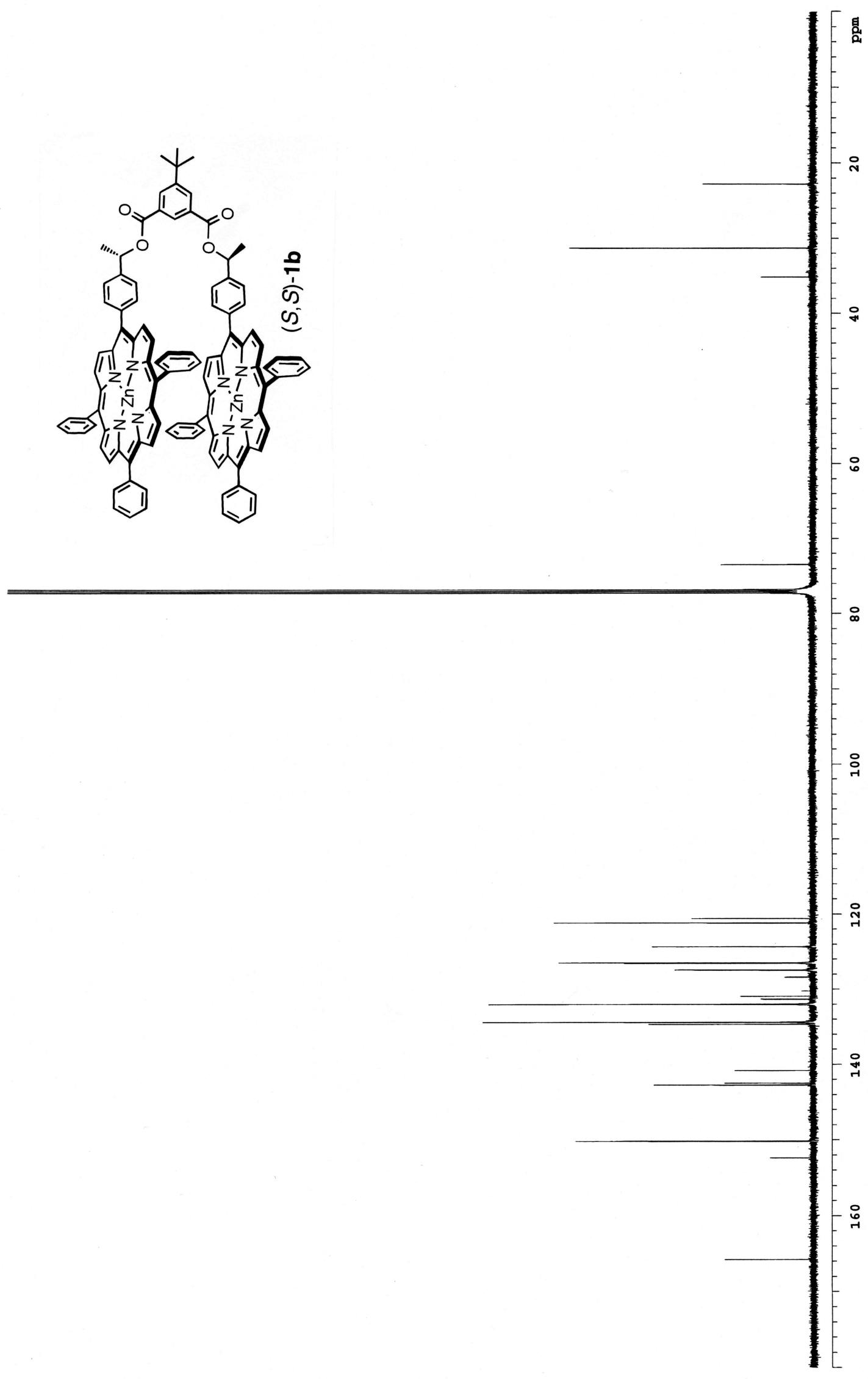

